\title{
CGAS wt Allele
}

National Cancer Institute

\section{Source}

National Cancer Institute. CGAS wt Allele. NCI Thesaurus. Code C106639.

Human CGAS wild-type allele is located in the vicinity of $6 q 13$ and is approximately $39 \mathrm{~kb}$ in length. This allele, which encodes cyclic GMP-AMP synthase protein, is involved in both immunity and cyclic nucleotide synthesis. 